\title{
Dural metastases with subdural hematoma from prostate cancer
}

\author{
M. Cobo Dols, S. Gil Calle, E. Villar Chamorro, I. Ales Díaz, A. Montesa Pino, J. Alcaide García, \\ V. Gutiérrez Calderón, F. Carabante Ocón, J. J. Bretón García, M. Benavides Orgaz
}

\section{Summary}

We reported a case of subdural effusion secondary to dural metastasis of prostatic cancer. A 54-year-old man was referred for headache, vomiting and gait disturbance. He had undergone hormonal therapy and docetaxelbased chemotherapy for prostatic cancer. The magnetic resonance imaging of the brain showed extensive leptomeningeal carcinomatosis and cranial dural metastases, and subdural hematoma. This is a very rare situation and bad prognosis.

\section{Key words:}

Prostate cancer. Dural metastases. Subdural hematoma.

Oncología, 2005; 28 (8):407-411 


\section{Resumen}

Decribimos el caso de un paciente de 54 años de edad con cáncer de próstata avanzado con hematoma subdural no traumático secundario a metástasis durales. Había recibido previamente tratamiento hormonal y quimioterapia basada en docetaxel. En la resonancia magnética se mostraba el hematoma subdural en el contexto de metástasis leptomeníngeas y durales. Hay que destacar esta forma tan inusual de metástasis de un cáncer de próstata y el mal pronóstico que conlleva esta complicación.

Palabras clave: Cáncer de próstata. Metástasis durales. Hematoma subdural.

\section{Case report}

A 54-year-old man underwent a radical prostatectomy in 1999 for adenocarcinoma of the prostate (Gleason score 3+4). He developed bone metastases in 2002 and received palliative radiotherapy in lumbar spine, two lines hormonal therapy (first with LHRH agonists plus concomitant use of antiandrogens, and second with megestrol acetate), and later strontium. After progression, at the first of 2005, with PSA $408 \mathrm{ng} / \mathrm{ml}$ and extensive bone spread in scintigraphy bone scan, he was treated with chemotherapy. The schedule was docetaxel $75 \mathrm{mg} / \mathrm{m}^{2}$ day 1 every 21 days plus prednisone $5 \mathrm{mg}$ twice per day, about 5 months. PSA levels decreased to $56 \mathrm{ng} / \mathrm{dl}$ and patient had a significant improvement in bone pain, quality of life and bone scan imaging.

Two months later, he was admitted with severe headaches, nausea and vomiting. Generalized hyperreflexia and left VII cranial nerve palsy were the only neurological abnormality on examination, and his PSA was markedly elevated respect previous level (318 ng/dl). His conscious level slight deteriorated over 72 hours. Computed tomography of the head revealed bony calvarial, suspect of dural metastatic disease without significant intracranial mass effect, and a chronic subdural hematoma. The magnetic resonance imaging of the brain showed no intracerebral disease, extensive dural metastases, and a chronic and acute non traumatic subdural hematoma (Figs. 1-3). He was treated with high-dose steroids. His response to steroids was good in control of symptoms in the first four days, and was programmed for palliative whole-brain radiotherapy. But Over a 3-days period, headaches and drowsiness re-

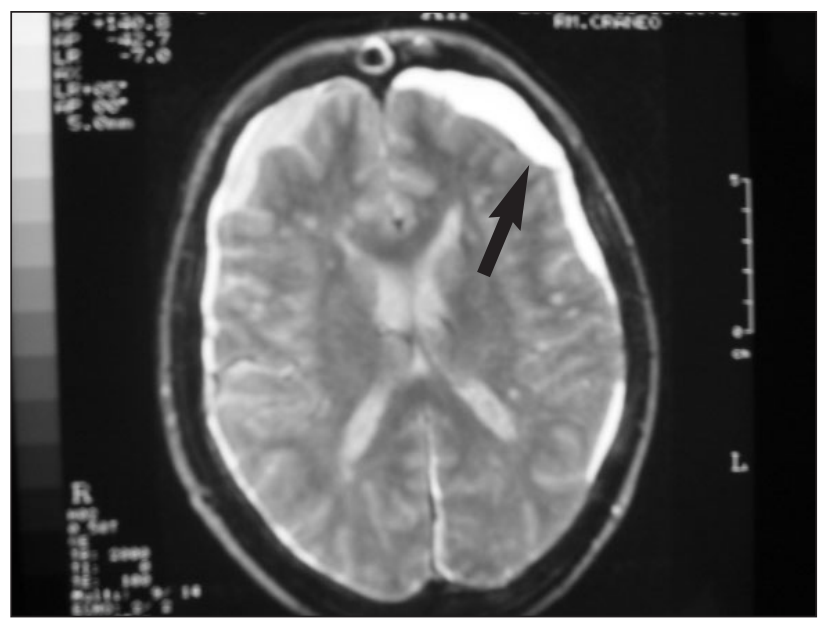

Figure 1. Brain Magnetic resonance: We show the vast distribution of dural metastases.

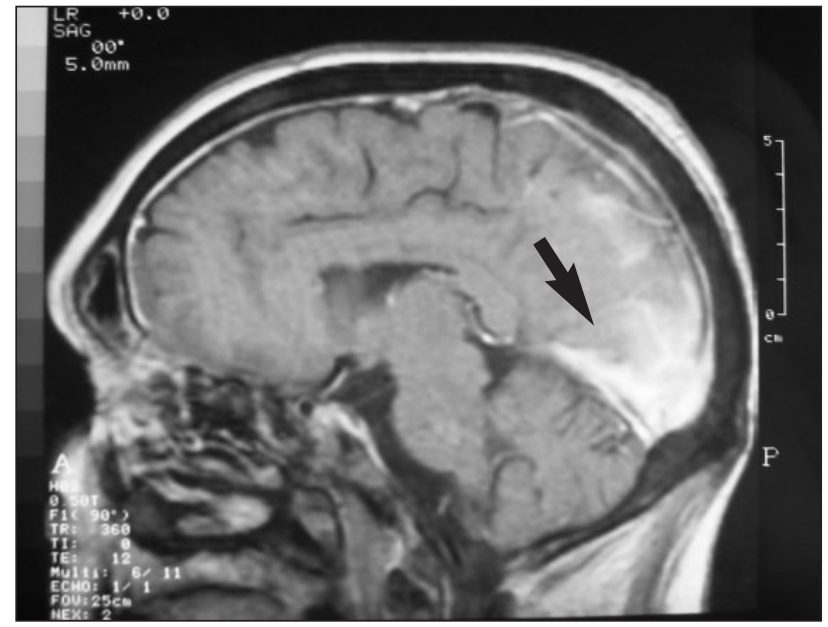

Figure 2. Brain Magnetic resonance. This is another imaging of dural metastases. 


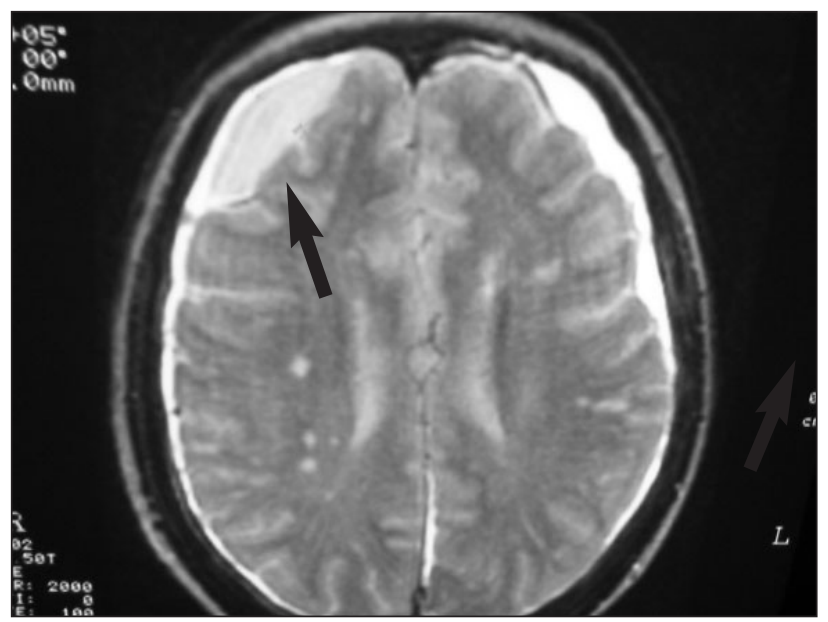

Figure 3. Brain Magnetic resonance. We show the imaging of subdural hematoma.

turned, his conscious level was deteriorated, and he did not respond to higher dose steroid therapy and died peacefully.

\section{Discussion}

Carcinoma of the prostate is predominantly a tumor of older men, which frequently responds to treatment when widespread and may be cured when localized. The system commonly used for the staging of prostate cancer. The Jewett system (stages A through $\mathrm{D}$ ) was described in $1975^{1}$.

The rate of tumor growth varies from very slow to moderately rapid, and some patients may have prolonged survival even after the cancer has metastasized to distant sites such as bone. Because the median age at diagnosis is 72 years, many patients (especially those with localized tumors) may die of other illnesses without ever having suffered significant disability from their cancer ${ }^{2}$. Survival of the patient with prostatic carcinoma is related to the extent of the tumor. If prostate cancer has spread to distant organs, current therapy will not cure it. Median survival is usually 1 to 3 years, and most such patients will die of prostate cancer. Even in this group of patients, however, indolent clinical courses lasting for many years may be observed ${ }^{3}$. As treatment options, hormonal manipulations have been effectively used as initial therapy for advanced prostate cancer. The standard first option is LHRH agonists used alone or with the initial concomitant use of antiandrogens ${ }^{4}$.
And in hormonal-refractory patients, the standard treatment is docetaxel-based chemotherapy as showed two recent randomised trials ${ }^{5,6}$.

The natural history and many aspects of the mechanism for distant metastasis is poorly understood. The cancer spreads to bone early, occasionally without significant lymphadenopathy. Currently, two predominant theories have been proposed for spread, the mechanical theory and the seed-and-soil theory. The mechanical theory involves direct spread through the lymphatics and venous spaces into the lower lumbar spine. Advocates of the seed-and-soil theory believe tissue factors must be present that allow for preferential growth in certain tissues, such as the bone. Lung, liver, and adrenal metastases have also been documented. Specific tissue growth factors and extracellular matrices are possible examples $^{7}$.

Neurologic complications continue to pose problems in patients with metastatic prostate cancer. From 15 to 30 percent of metastases are the result of prostate cancer cells travelling through Batson's plexus to the lumbar spine. Metastatic disease in the lumbar area can cause spinal cord compression. Brain metastasis is rare in prostate cancer and occurs late in the course of the disease. It occurs in 1 to 2 percent of patients with metastatic prostate cancer and usually represents the failure of hormonedeprivation therapy and the presence of disseminated disease $^{8}$. Data collected before the importance of PSA values was recognized indicate that the average time from the diagnosis of prostate cancer to the occurrence of metastasis is 19 months for bone metastasis, 35 months for lung metastasis, and 60 months for brain metastasis ${ }^{9,10}$. The long time between diagnosis and brain involvement strongly favours the cascade theory of tumor spread. Metastasis to the brain can occur by way of Batson's plexus or by direct extension from adjacent structures such as the sphenoid bone or sinuses ${ }^{11}$. The most common intracranial sites of prostate cancer metastasis are the leptomeninges (67 percent), cerebrum (25 percent), and cerebellum ( 8 percent $)^{9}$. Other primary cancers, such as lung and breast tumors, are more likely to have intraparenchymal metastases than leptomeningeal involvement. Patients rarely present with neurologic symptoms as the first manifestation of prostate cancer. Presentation with a solitary brain metastasis as the only site of prostate cancer spread is 
even more rare. Leptomeningeal metastasis (or carcinomatosis) is usually clinically silent, although it can present with deficits in multiple anatomic site ${ }^{12}$. No test other than gadolinium-enhanced MRl is required to exclude or confirm the presence of brain metastases. Compared with CT scanning, MRl is more sensitive in detecting multiple metastases, especially at the graywhite junction ${ }^{13}$. Respect the treatment, Dexamethasone therapy should be started early, and A two-week course of radiotherapy is the most common treatment for patients with multiple brain metastases or leptomeningeal metastasis ${ }^{14}$.

So, leptomeningeal carcinomatosis secondary to prostatic tumor has been reported, but cranial dural metastases from prostatic adenocarcinoma have been described anecdotally ${ }^{15-17}$. Non traumatic subdural hematoma secondary to dural metastases is a rare event. We could find in the literature less than $40 \mathrm{ca}-$ ses of subdural hematoma or effusion secondary to dural metastasis of carcinoma ${ }^{18,19}$. But Nontraumatic subdural hematoma secondary to dural metastasis from adenocarcinoma of the prostate was encountered in only 4 patients ${ }^{18,20,21}$.

The mechanism by which dural metastases occur in prostate cancer is controversial. Frequently there is evidence of direct tumour extension from skull metastases ${ }^{22}$. To explain the occasional cases where there is no evidence of direct tumour extension it has been suggested that metastatic deposits could arise in the dura by invasion of the dural veins via the Blaxon's plexus ${ }^{23}$. Haematogenous spread of cancer cells to the dura from systemic malignant disease has also been suggested ${ }^{24}$. Autopsy series ${ }^{24,25}$ have found that most of the prostate cancer cases have associated lung involvement, especially lymphangitic and intravascular spread, implying a heavy vascular tumour burden ${ }^{25}$. There have been occasional reports of surgical intervention for subdural metastases in prostate cancer with varying degrees of success ${ }^{24}$. The scarcity of prostate cancer in surgical series compared with autopsy series suggests that in prostate cancer dural metastases may well be an end-stage phenomenon, being associated with advanced disease. The pathogenesis of the subdural hematoma in this case might be due to circulatory disturbance at the dura mater brought about by the invasion of the tumor or tumor cells emboli in the capillaries. So, vascular obstruction due to invasion of dural vessels is an important etiological factor ${ }^{21}$.
Because neurologic complications of metastatic prostate cancer require prompt treatment, early recognition is important. Physicians should consider metastasis in the differential diagnosis of newonset low back pain or headache in men more than 50 years of age.

\author{
Correspondence: \\ Dr. M. Cobo Dols \\ Secretaría del Servicio Oncología Médica \\ Pabellón A. $3^{\mathrm{a}}$ planta. Derecha \\ Hospital Regional Universitario Carlos Haya \\ Avd. Carlos Haya, s/n \\ E-29010 Málaga \\ E-mail: manuelcobodols@yahoo.es \\ mangel.cobo.sspa@juntadeandalucia.es
}

\section{Bibliografia}

1. Jewett HJ. The present status of radical prostatectomy for stages A and B prostatic cancer. Urol Clin North Am 1975; 2 (1): 105-24.

2. Garnick MB. Prostate cancer: screening, diagnosis, and management. Ann Intern Med 1993; 118 (10): 804-18.

3. Gittes RF. Carcinoma of the prostate. N Engl J Med 1991;324 (4): 236-45.

4. David J, Samson DJ, Seidenfeld J, Schmitt B, Hasselblad V, Albertsen PC, et al. Systematic Review and MetaAnalysis of monotherapy Compared with Combined Androgen Blockade for Patients with Advanced Prostate Carcinoma. Cancer 2002;95:361-76.

5. Tannock IF, de Wit R, Berry WR. Docetaxel plus prednisone or mitoxantrone plus prednisone for advanced prostate cancer. N Engl J Med 2004;351 (15): 1502-12.

6. Petrylak DP, Tangen CM, Hussain MH. Docetaxel and estramustine compared with mitoxantrone and prednisone for advanced refractory prostate cancer. N Engl J Med 2004;351 (15): 1513-20.

7. Hsing AW, Tsao L, Devesa SS: International trends and patterns of prostate cancer incidence and mortality. Int J Cancer 2000 Jan 1; 85(1): 60-7.

8. Benjamin R. Neurologic complications of prostate cancer. Am Fam Physician 2002 May 1;65(9):1834-40.

9. Lynes WL, Bostvi'ick DG, Freiha FS, Stamey TA, Parenchyma brain metastases from adenocarcinoma of prostate. Urology 1986;28:280-7.

10. Varkarakis MJ, Winterberger AR, Gaeta J, Moore RH, Murphy GP. Lung metastases in prostatic carcinoma. Clinical significance. Urology 1974;3:447-52. 
11. Capito PR, Wang H, Brem H, Ahn HS, Bryan RN. Magnetic resonance imaging diagnosis of an intracranial metastasis of adenocarcinoma of the prostate: case report. Med J 1991:40:113-5.

12. Balm M, Hammack J. Leptomeningeal carcinomatosis. Presenting features and prognostic factors. Arch Neuro 1996;53:626-32.

13. De Angelis LM, Metastatic disease of the nervous system. Curr Treat Options Neurol 1999;1:409-16.

14. Patcheil RA. The treatment of brain metastases. Cancer Invest 1996;14:169-77.

15. Penley MW, Kim YC, Pribram HF. Subdural metastases from prostatic adenocarcinoma. Surg Neurol 1981 Aug;16(2):131-4.

16. Bentley AM, Keen JC. Dural metastases in prostate cancer. Clin Oncol (R Coll Radiol) 2003 May;15(3):165-6.

17. Scarrow AM, Rajendran PR, Marion. Metastatic prostate adenocarcinoma of the dura mater. Br J Neurosurg 2000 Oct; 14(5):473-4.

18. Tasaki K, Shima T, Matsumura S, Okada Y, Nishida M, Yamada $\mathrm{T}$, et al. A case of subdural effusion secondary to dural metastasis of prostatic cancer:case report. No Shinkei Geka 1990 Jun;18(6):539-42.
19. Ambiavagar PC, Sher J. Subdural hematoma secondary to metastatic neoplasm: report of two cases and a review of the literature. Cancer 1978 Oct;42(4):2015-8.

20. Varlet G, N'Dri Oka D, Kakou M, Echimane A, Ba Zeze V. Secondary subdural hematoma in dural metastasis of prostatic adenocarcinoma. Rev Neurol 2001 Dec;157 (12):1543-5.

21. Bucci MN, Farhat SM. Metastatic adenocarcinoma of the prostate as a cause of subdural hematoma. J Urol 1986 Apr;135(4):803-4.

22. Kleinschmidt-DeMasters BK. Dural metastases - a retrospective surgical and autopsy series. Arch Path Lab Med 2001; 125:880-887.

23. Smith VC, Kasdon DL, Hardy RC. Metastatic brain tumour from the prostate: two unusual cases. Surg Neurol 1980; 14:189-191.

24. Rumana CS, Hess HR, Shi WM, Sawaya R. Metastatic brain tumors with dural extension. J Neurosurg 1998; 89;552-558.

25. Castaldo JE, Bernat JL, Meier FA, Schned AR. Intracranial metastases due to prostate carcinoma. Cancer 1983; 52:1739-1742. 